\title{
IDEOLOGI PURITAN DALAM TAFSIR JAWA PESISIR: KAJIAN TERHADAP PENAFSIRAN MISBAH MUSTOFA
}

\author{
Aunillah Reza Pratama \\ UIN Sunan Kalijaga Yogyakarta \\ aunillahreza@gmail.com
}

\begin{abstract}
The study examines the interpretation of the Coastal Javanese figure, Misbah Mustofa, who seems paradoxical to the traditionalist style of Islam which lies behind his socio-religious background. Misbah's interpretation, indeed, shows the model of puritanical Islam. By using Hans Georg Gadamer's hermeneutics, this article discusses Misbah's interpretation of the QS. al-Baqarah [2]: 134, where he put his critics towards Javanese tradition, like tablilan. The puritan style of Misbah's interpretation is caused by several factors: First, the ideology of Coastal Javanese santri that makes Islamic sharia as a standard reference of religious teaching which tends to be more critical towards syncretic tradition of Javanese cults and rites. Second, Misbah's pre-understanding of heresy and shirk. Third, the interpretation based on the general meaning, tends to be more textualist, and seems to ignore the virtue of socio-religious life of the community. The meaningful sense of Misbah's interpretation is critical attitude towards religious teaching and proportionally locating permissive and conservative attitude in order to maintain the coexistance of religion and culture.
\end{abstract}

Keywords: Misbah Mustofa, Puritanism, Javanese Interpretation, Traditional Islam.

Abstrak: Penelitian ini mengkaji penafsiran ulama Jawa Pesisir, Misbah Mustofa, yang tampak paradoks dengan corak Islam tradisionalis yang menjadi background sosial-keagamaannya. Penafsiran Misbah justru menampilkan paham Islam puritan. Dengan menggunakan pendekatan hermeneutika Hans George Gadamer, penelitian ini hendak melihat penafsiran Misbah terhadap QS. alBaqarah [2]: 134, yang mengkritik tahlilan, sebuah tradisi yang subur di masyarakat lokal Jawa pesisir. Corak tafsir puritan Misbah disebabkan oleh beberapa faktor, di antaranya: Pertama, ideologi kaum santri Jawa Pesisir yang menjadikan syariat Islam sebagai acuan baku dalam beragama, sehingga cenderung kritis terhadap tradisi sinkretis 
masyarakat Jawa. Kedua, pra-pemahaman Misbah tentang bidah dan syirik. Jika bidah tersebut dalam ranah 'ubudiyah dan i'tiqadiyyah maka dianggap sesat dan dilarang. Ketiga, penafsiran yang berbasis pada makna umum ayat, lebih cenderung pada pemaknaan tekstualis, serta kurang melihat aspek kemaslahatan dalam kehidupan sosio-religi masyarakat. Meaningful sense atau nilai yang tercermin atas sikap Misbah dalam kajian ini yaitu kritis dalam beragama serta meletakkan sikap permisif dan konservatif secara proporsional untuk menjaga eksistensi antara agama dan budaya.

Kata Kunci: Misbah Mustofa, Puritanisme, Tafsir Jawa, Islam Tradisional.

\section{Pendahuluan}

Dalam dinamika sejarah, tafsir Alquran Indonesia lahir dari ruang sosial kebudayaan yang beragam. Mulai dari era 'Abd al-Ra'ū alSinkili pada abad ke-17 M hingga era Muhammad Quraish Shihab pada abad ke-21 M. ${ }^{1}$ Dalam kurun waktu tersebut, berbagai karya tafsir Indonesia lahir dalam ruang sosio-kultural yang beragam. Interaksi Alquran dengan beragam kondisi lokal sosial budaya di Indonesia telah melahirkan berbagai macam praktik tradisi keagamaan di masyarakat. ${ }^{2}$ Dengan kenyataan inilah, setidaknya nilai-nilai dalam Alquran telah banyak mengilhami masyarakat hingga termanifestasikan dalam berbagai macam ritus keagamaan.

Ketika menyandingkan Islam dan Jawa, maka yang terlintas dalam pikiran adalah berbagai praktik keagamaan dengan segala macam ritualnya, yang tentunya kental dengan nuansa lokalitasnya. Fenomena demikian pada akhirnya terbingkai dalam sebuah terma yang disebut dengan Islam kejawen. Islam kejawen merupakan hasil dari dakwah kreatif para Walisongo dalam mengislamisasi masyarakat Jawa pada kisaran abad ke-15. Perlu disadari bahwa Islam datang ke Indonesia ketika ajaran dan tradisi Hindu-Buddha sudah lama mengakar di masyarakat, khususnya masyarakat Jawa. ${ }^{3}$ Maka, perlu usaha kreatif agar ajaran-ajaran Islam mampu diterima oleh masyarakat Jawa saat itu. Salah satu usaha para Walisongo adalah dengan melakukan sinkretisasi tradisi lokal dengan nilai-nilai

${ }^{1}$ Islah Gusmian, "Tafsir Alquran di Indonesia: Sejarah dan Dinamika," dalam NUN Jurnal Studi Alqur'an dan Tafsir di Nusantara, Vol. 1, No. 1, (2015), 4.

${ }^{2}$ Heddy Shri Ahimsa, "The Living Alquran: Beberapa Perspektif Antropologi," dalam Jurnal Walisongo, Vol. 20 No. 1 (2012), 235.

${ }^{3}$ Gusmian "Tafsir Alquran di Indonesia," 7. 
keislaman. Dari sinilah kemudian muncul istilah Islam sinkretis, yaitu Islam yang bersinergi dengan tradisi lokal yang kemudian melahirkan suatu corak keagamaan yang bersifat lokal dan tradisional. ${ }^{4}$

Di sisi lain, muncul pula sebuah gerakan purifikasi atau pemurnian ajaran Islam dari praktik-praktik TBC (tahlil, bidah, churofat) yang dianggap keluar dari ajaran Islam. Diskursus pro dan kontra kemudian menghampiri alam pemikiran masyarakat dalam menyikapi fenomena Islam kejawen ini. Setidaknya, persoalan ini berpangkal dari wacana bidah dan syirik yang menjadi akar dari problematika fenomena ini. Gerakan purifikasi selalu identik dengan kelompok Islam puritan. ${ }^{5}$ Islam puritan sendiri memiliki misi untuk menetralisir ajaran-ajaran Islam dari segala macam praktik keagamaan yang mengarahkan pada kesyirikan. Mereka ingin mengembalikan Islam pada ajaran baku yang terdapat dalam Alquran dan hadis. ${ }^{6}$ Pergulatan wacana dan gagasan di kalangan para ulama Indonesia terkait hal ini terus berlangsung. Kelompok yang pro atas Islam kejawen ini di antaranya adalah NU (Nahdhatul Ulama), salah satu ormas Islam dengan anggota terbanyak di Indonesia yang selalu diidentikan dengan Islam tradisional. ${ }^{7}$

Dalam konteks inilah kemudian muncul fenomena menarik di mana sikap paradoks justru ditampakkan oleh seorang ulama dan mufassir dari kalangan Islam tradisionalis, Misbah Mustofa. Melalui kitab tafsirnya, Misbah justru melakukan kritik terhadap praktikpraktik Islam kejawen yang mengurat nadi di masyarakatnya. Tidak jarang dia menyebut terminologi khas Islam puritan, seperti bidah, yang ditujukan untuk praktik-praktik keislaman tradisional. Seperti penafsirannya terhadap QS. al-Baqarah [2]:134,

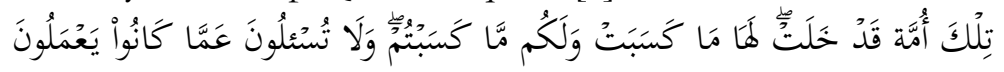

"Itulah umat yang telah lalu. Baginya apa yang telah mereka usahakan dan bagimu apa yang telah kamu usahakan. Dan kamu tidak akan diminta (pertanggungjawaban) tentang apa yang dahulu mereka kerjakan"

Dalam penafsirannya, Misbah menyatakan bahwa praktik yang sering dilakukan di masyarakatnya seperti tawasul atau

${ }^{4}$ Sutiyono, Benturan Budaya Islam Puritan dan Sinkretis, (Jakarta: Kompas, 2010), 13.

5Ibid., 9.

'Ibid., 11.

${ }^{7}$ Munawar Abdul Fattah, Tradisi Orang-orang NU (Yogyakarta: Pustaka Pesantren, 2006), xiv. 
mengkhususkan pahala sebuah ibadah bagi orang yang sudah mati merupakan hal yang sia-sia, bertentangan dengan ayat di atas, dan merupakan perilaku bidah. ${ }^{8}$ Dari sini dapat digarisbawahi bahwa gagasan tersebut tampak sejalan dengan ide Islam puritan yang mengusung misi pemurnian agama dari tradisi sinkretik.

Sikap Misbah tersebut tentunya tampak paradoks dengan kondisi sosio-historis yang melatarbelakanginya, melihat bahwa Misbah Mustofa merupakan salah satu ulama tradisional di masanya. Bahkan ia menjadi salah satu pemimpin/pengasuh pondok pesantren tradisional di daerah Tuban. Di sisi lain, ia adalah sosok yang tumbuh dan besar di lingkungan masyarakat Jawa yang tentunya tidak asing dan berinteraksi secara langsung dengan tradisi dan budaya itu. Ditambah lagi, fakta bahwa ia juga merupakan salah satu tokoh NU yang aktif di masanya, di mana NU sangat lekat dengan tradisi-tradisi tersebut.' Maka wajar jika pada masanya, ia dikategorikan sebagai ulama NU dengan fikrah pinggiran. Sebutan ini diafiliasikan kepada orang NU yang sering berseberangan atau berbeda pendapat dengan pemikiran mayoritas ulama NU, dan pemikiran tersebut cenderung kontroversial di kalangan mereka. ${ }^{10}$

Berangkat dari wacana tersebut, tulisan ini hendak melakukan kajian hermeneutik terhadap penafsiran Misbah Mustofa yang mengindikasikan adanya gagasan Islam puritan. Fokus tulisan ini hendak menganalisa penafsiran Misbah terhadap QS. al-Baqarah [2]: 134, yang di dalamnya mengekspresikan simbol-simbol puritanisme dengan mengkritik praktik keislaman tradisional. Dengan perspektif hermeneutik, tulisan ini berusaha untuk mengetahui alasan dan nilai atas gagasan yang diekspresikan oleh Misbah Mustofa, mengurai paradoks kultural dalam penafsirannya, kemudian meletakkannya pada pemahaman yang proporsional di masanya.

\section{Sekilas Tentang Misbah Mustofa}

\footnotetext{
${ }^{8}$ Misbah Mustofa, Taj al-Muslimin Min Kalam Rabb al-'Alamin (Tuban: Majelis Ta'lif wal Khattāt, 1990), 402.

"Ahmad Baidowi, "Aspek Lokalitas dalam Tafsir al-Iklil," dalam NUN Jurnal Studi Alqur'an dan Tafsir di Nusantara, Vol. 1, No. 1 (2015), 38.

${ }^{10}$ Siti Asmah, Biografi dan Pemikiran KH. Misbah Mustofa Bangilan Tuban (1919-

1994 M), Skripsi, IAIN Sunan Ampel, 2012, 57
} 
Misbah Zainal Mustofa, atau Masruh, sebutan masa kecilnya, adalah putra dari Zainal Mustofa dan Khadijah. Ia dilahirkan pada tahun 1917 di Kampung Sawahan, Gang Palem, Rembang, Jawa Tengah. ${ }^{11}$ Misbah merupakan seorang kiai di Pondok Pesantren AlBalagh yang berada di Bangilan, Tuban, Jawa Timur. Selain berjuang sebagai ulama pendiri Pesantren, Misbah juga aktif dalam organisasi sosial Nahdhatul Ulama' (NU). Meski tidak tercatat sebagai pengurus struktural, kiprahnya dalam NU telah mewarnai corak pemikirannya. NU sendiri merupakan sebuah wadah sosial keislaman yang banyak membicarakan permasalahan-permasahan sosial dan hukum Islam dengan beragam adat dan tradisi masyarakat yang melingkupinya. Dalam hal inilah, Misbah sering berseberangan dengan pendapatpendapat mayoritas ulama NU. Dia juga kemudian dikategorikan sebagai ulama NU dengan fikrah pinggiran, yang sering diafiliasikan kepada ulama NU yang memiliki pemikiran berbeda dari mayoritas ulama NU lainnya. ${ }^{12}$

Misbah memiliki keuletan dan ingatan yang tajam. Hal itu diperoleh dari kesungguhan memperdalam keilmuannya dengan mempelajari berbagai macam kitab-kitab klasik. Dia juga menghafal Alquran dan hadis. Dia juga dikenal sebagai orang yang berpendirian teguh dan memegang prinsip yang kuat. Jika dihadapkan pada suatu masalah, dia seringkali mempelajarinya dengan banyak merujuk pada Alquran dan hadis serta pendapat ulama salaf. ${ }^{13}$ Apapun hasil atau kesimpulan yang diperolehnya, dia tidak mempedulikan apakah orang lain akan menerima atau menolaknya.

Misbah terkenal sebagai ulama yang produktif menulis dan melahirkan banyak karya. Kitab tafsir Al-Iklìl dan Taj al-Muslimin merupakan karya monumental dalam bidang tafsir yang sampai sekarang masih banyak dikaji oleh masyarakat pedesaan. Kedua kitab tersebut ditulis menggunakan huruf pegon, bahasa Jawa yang ditulis dengan huruf Arab. Penafsiran dengan menggunakan bahasa Jawa tersebut tentu bertujuan untuk memudahkan masyarakat Jawa pesisir, khususnya kalangan 'santri', untuk membaca dan memahami maksud dari penafsirannya. Dia meninggal di tengah kesibukannya menyusun

\footnotetext{
${ }^{11}$ Supriyanto, "Alquran dalam Ruang Keagamaan Islam Jawa: Respons Pemikiran Keagamaan Misbah Mustofa dalam Tafsir al-Iklil," dalam Jurnal Theologia, Vol. 28, No. 1 (2017), 33.

${ }^{12}$ Asmah, "Biografi dan Pemikiran," 57.

${ }^{13}$ Baidowi, "Aspek Lokalitas," 38.
} 
karya tafsir pada usia 78 tahun, tepatnya hari Senin 7 Zulqadah 1414 H, 18 April $1994 \mathrm{M}^{14}$

\section{Corak Ideologi Puritan Dalam Kitab Tafsir Misbah Mustofa 1. Penafsiran Misbah terhadap QS. Al-Baqarah [2]: 134}

Dalam surah al-Baqarah [2]: 134, Misbah menyinggung salah satu praktik tahlilan yang dianggap masih menyerupai ruwatan. Ruwatan merupakan upacara mendoakan roh-roh para leluhur. Dalam perkembangan sejarahnya, tradisi ruwatan ini kemudian digubah oleh ulama Islam menjadi tahlilan. Pada dasarnya, praktik tahlilan masih sama dengan ruwatan. Hanya digubah isi doanya dengan doa-doa yang sesuai dengan ajaran Islam, seperti membaca surah Yàsin, al-Ikhlaṣ, al-Falaq, dan al-Nâs, yang pahalanya dikhususkan bagi orang yang sudah meninggal.

Terhadap praktik demikian, Misbah mengkritik masalah pengiriman pahala kepada orang lain. Sebagaimana yang termaktub dalam kitabnya:

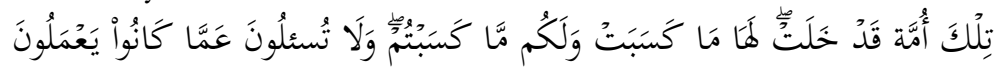

"itulah umat yang telah lalu. Baginya apa yang telah mereka usahakan dan bagimu apa yang telah kamu usahakan. Dan kamu tidak akan diminta (pertanggungjawaban) tentang apa yang dahulu mereka kerjakan."

Terhadap ayat tersebut Misbah menafsirkan bahwa seseorang tidak akan mendapatkan pahala dari kebaikan yang dilakukan orang lain. Sama halnya dengan pengiriman pahala kepada orang yang sudah meninggal yang lumrah dilakukan oleh masyarakat Jawa dan tradisi itu biasa disebut dengan praktik tahlilan. Dengan lebih jelas, dia menuliskan:

"seorang tidak akan dapat menerima pahala dari orang lain. Seorang anak tidak akan dapat menerima pahala dari kebaikan orang tuanya atau para leluhurnya. Segala amal yang dilakukan seorang akan kembali pada dirinya sendiri dan seorang tidak akan menanggung dosa orang yang lain. Di akhirat nanti jelas tidak ada orang yang bisa memperoleh manfaat dari kebaikan orang lain. Kecuali orang tersebut mau menunjukkan orang untuk menjalankan kebaikan, sebagaimana sabda Nabi "man dalla 'ala khayrin fa labü mithl ajr fá'ilih. Dari hadis-hadis dan ayat Alquran di

\footnotetext{
${ }^{14}$ Supriyanto, “Alquran dalam Ruang Keagamaan,” 35.
} 
atas, jelas jika orang yang sudah meninggal tidak dapat menerima manfaat amal dari orang lain." 15

Menurut Misbah, orang yang sudah meninggal tidak dapat memberi atau menerima manfaat pahala dari orang yang masih hidup. Konsekuensi atas pemahaman tersebut adalah bahwa tawasul dan tahlilan yang dimaksudkan untuk mengirim pahala pada orang yang sudah meninggal adalah perbuatan sia-sia dan tidak ada manfaatnya. Ia juga memaparkan ayat-ayat lain yang senada dengan QS. al-Baqarah [2]: 134 sebagai argument pendukung, seperti QS. al-An`ām [6]: 164, QS. al-Nisā' [4]: 123, QS. 'Abasa [80]: 34-37 dan al-Najm [53]: 39.

Namun demikian, Misbah tidak memungkiri adanya pengecualian dalam hal pengiriman pahala kepada orang yang sudah meninggal. Ia menjelaskan bahwa orang yang sudah meninggal dapat menerima pahala dari orang lain dalam keadaan tertentu. Ia mencontohkan dengan seseorang yang menunjukkan jalan kebaikan kepada orang lain dan orang itu melakukan kebaikan berdasarkan petunjuknya, maka orang yang menunjukkan jalan kebaikan itu akan mendapat pahala sebagaimana orang yang menjalankannya, meskipun dia telah meninggal. Ia mengutip hadis "man dalla 'alà khayrin fa labū mithl ajr fäilib."

Misbah menambahkan bahwa seseorang yang sudah meninggal bisa mendapatkan pahala dari orang lain, yaitu pahala dari sedekah dan doa. Hal tersebut berdasarkan pada beberapa hadis yang menerangkan tentang amal perbuatan yang dapat memberikan manfaat bagi orang yang sudah mati. Menurutnya, QS. al-Baqarah [2]: 134 merupakan ayat yang 'am (umum) yang kemudian di-takhsiis (dikhususkan) oleh hadis-hadis di atas. Jadi, kesimpulan yang diambil Misbah adalah QS. al-Baqarah [2]: 134, yang secara umum mengandung arti seseorang tidak bisa mendapat manfaat dari amal orang lain, telah di-takbsisis oleh hadis yang disebutkan pada kitabnya, yang secara pokok ada pada amal sedekah dan doa. ${ }^{16}$ Jadi, Misbah menyimpulkan bahwa seseorang tidak bisa mendapat manfaat dari perbuatan orang lain, jika amalnya bukan berupa amal doa ataupun sedekah. Misbah tidak serta merta menolak pandangan yang membenarkan pahala amal orang lain dapat dikirimkan kepada orang yang meninggal.

\footnotetext{
${ }^{15}$ Mustofa, Al-Iklïl, vol. I, 127-128.

${ }^{16}$ Ibid., 129.
} 
Hal tersebut berdasarkan pada beberapa hadis yang menerangkan tentang amal perbuatan yang dapat memberikan manfaat bagi orang yang sudah mati. Dengan mengutip al-Suyūtịi, dia memerinci beberapa amal tersebut kepada sepuluh amal, yaitu: a) Mengajarkan Ilmu Alquran; b) Doa anak kepada orang tuanya; c) Menanam tanaman yang buahnya dapat memberikan manfaat bagi masyarakat; d) Sedekah jariyah, seperti wakaf atau mewariskan mushaf; e) Menjaga tempat perlindungan dari serangan musuh; f) Membuat sumur untuk masyarakat umum; g) Mengalirkan air sungai (membuat aliran untuk air sungai agar bisa dimanfaatkan airnya, seperti irigasi); h) Membangun rumah bagi orang asing; i) Membangun bangunan untuk Majlis dzikir, seperti masjid atau mushola; j) Mengajarkan Alquran.

Kesepuluh amal di atas merupakan intisari beberapa hadis yang menjelaskan pahala amal perbuatan yang bisa didapatkan oleh orang yang sudah meninggal, yang kemudian oleh al-Suyuți dijadikan syair. Oleh Misbah, hadis-hadis tersebut secara zahir bertentangan dengan ayat yang ditafsirkan di atas. Namun menurutnya, al-Baqarah [2]: 134 merupakan ayat yang 'amm yang kemudian di-takhsis oleh hadis-hadis di atas. Jadi, kesimpulan yang diambil Misbah adalah surah al-Baqarah: 134, yang secara umum mengandung arti seseorang tidak bisa mendapatkan manfaat dari amal orang lain, telah di-takhsis oleh sepuluh amal di atas, yang secara pokok ada pada amal sedekah dan doa. ${ }^{17}$ Jadi, Misbah menyimpulkan bahwa seseorang tidak bisa mendapatkan manfaat dari perbuatan orang lain jika amalnya bukan berupa amal doa ataupun sedekah. Misbah tidak serta merta menolak pandangan yang membenarkan pahala amal orang lain dapat dikirimkan kepada orang yang meninggal.

Kemudian dalam surah al-Baqarah, bunyi ayat ke-134 diulang kembali pada ayat ke-141. Pada QS. al-Baqarah [2]: 141 ini, Misbah menegaskan kembali tentang pentingnya kesadaran diri untuk tidak mengandalkan orang lain dalam hal ibadah. Misbah memberikan contoh tentang tradisi tahlil. Misbah tampak khawatir dengan adanya realita tradisi tahlil, seseorang akan menyepelekan urusan ibadahnya. Sebab ketiak dia mati, keluarga dan orang lain nantinya masih bisa memberikan pahala dan doa melalui prosesi tahlilan. ${ }^{18}$ Inilah barangkali yang menjadi pangkal pokok pikiran Misbah untuk tidak

${ }^{17}$ Ibid.

${ }^{18} \mathrm{Ibid} ., 138$. 
menerima secara taken for granted, namun juga tidak menolak secara keseluruhan akan tradisi tersebut.

Dalam kitab tafsir Taj al-Muslimin, terkait QS. al-Baqarah[2]: 134, dijelaskan bahwa tahlilan merupakan tindakan yang tidak dilarang oleh agama Islam. Tahlilan yang dianggap boleh oleh Misbah adalah tahlilan yang dikhususkan untuk berzikir dan berdoa secara berjamaah. Bahkan ia menganjurkan untuk tetap mengadakan tradisi tahlilan. Walaupun tradisi tahlilan ini tidak ada di masa Nabi ataupun Sahabat, menurut Misbah, tradisi ini telah mendapatkan izin shar $\bar{i}$ dari hadis:

$$
\text { اذا مررتم برياض الجنة فا رتفعوا ,وما رياض الجنة؟ قال حلق الذكر }
$$

"Jika kalian melewati taman surga, maka ikutlah berzikir. Para sahabat bertanya: apa taman surga itu? Nabi menjawab: Taman Surga adalah majelis orang-orang yang sedang berzikir." ${ }^{\text {19 }}$

Sedangkan tahlilan yang dia anggap sebagai bidah dan tidak dibenarkan oleh agama Islam adalah tahlilan yang telah mengalami modifikasi yang menyerupai tradisi-tradisi sinkretik. Bentuk tahlilan tersebut, misalnya, harus dilakukan pada waktu-waktu yang telah dikhususkan yang kemudian memunculkan anggapan bahwa seolah tahlilan tidak akan sah jika tidak dilakukan pada rangkaian hari yang telah ditentukan, seperti telung dino (tiga hari), mitung dino (tujuh hari), nyatus (seratus hari) dan baul (setahun) dalam rangkaian prosesi tahlilan. Praktik tahlilan yang demikian, menurut Misbah, termasuk dalam kategori bidah dalam ibadah dan tidak sejalan dengan ajaran agama. Menurutnya, hakikat dari tahlilan adalah berzikir serta mendoakan mayit agar diberi ampunan oleh Allah. ${ }^{20}$ Jadi, perlu digarisbawahi bahwa titik penting dalam pemikiran Misbah adalah tahlil berfungsi sebagai doa untuk orang meninggal, bukan sebagai medium untuk mengirim 'pahala' kepada mereka.

\section{Analisis Hermeneutika Terhadap Penafsiran Misbah Mustofa}

Hans George Gadamer memberikan tawaran konsep hermeneutika bahwa membaca dan memahami sebuah teks pada dasarnya adalah melakukan dialog dan membangun sintesis triadik antara dunia teks, dunia pengarang dan dunia pembaca. Ketiga hal ini

\footnotetext{
${ }^{19}$ Ibid.

${ }^{20}$ Ibid., 409.
} 
memberi kontribusi penting dalam konstruksi sebuah pemahaman. ${ }^{21}$ Kemudian, untuk mendapatkan pemahaman yang maksimal, Gadamer menawarkan empat teori, yaitu kesadaran keterpengaruhan sejarah, pra-pemahaman, lingkaran hermeneutik atau asimilasi horizon dan aplikasi. Asumsi dan teori Gadamer ini menjadi starting point untuk menganalisa lebih dalam sisi historisitas penafsiran Misbah, yang kemudian dengan pertimbangan tersebut akan melahirkan pemahaman yang komprehensif dan proporsional ketika membaca panafsiran Misbah dalam konteks kekinian.

\section{Historisitas Penafsiran Misbah Mustofa}

\section{a. Ideologi Kaum Santri Jawa Pesisir}

Penelitian Geertz, dalam buku monumentalnya yang berjudul The Religion of Java, terhadap kultur keagamaan masyarakat Jawa telah terlanjur berpengaruh kepada kajian-kajian etnografi masyarakat Jawa. Teori trikotomi yang dia gagas untuk memetakan keberagamaan masyarakat Islam Jawa juga banyak menuai kritik dari berbagai peneliti. Namun, terlepas dari kritik terhadap teorinya, dikotomi masyarakat Jawa santri, abangan dan priyayi telah menjelma menjadi sebuah term yang digunakan untuk menggolongkan model keberagamaan masyarakat Islam Jawa. Salah satu trikotomi tersebut, yaitu priyayi, menjadi sorotan kritik yang sering muncul, karena dianggap tidak relevan jika dimasukkan dalam peta tipologi keberagamaan masyarakat Jawa. ${ }^{22}$ Priyayi dianggap sebagai term yang mengarah pada stratifikasi sosial dan identik dengan istilah wong cilik. Sehingga, priyayi tidak relavan jika dimasukkan dalam kategorisasi keberagamaan masyarakat Islam Jawa.

Pada perkembangan selanjutnya, istilah santri dan abangan mendapat tempat tersendiri dalam kajian-kajian etnografi masyarakat Islam Jawa. Meskipun dua istilah tersebut tidak secara merata digunakan oleh orang Jawa, namun pada intinya adalah untuk mengidentifkasi orang-orang Islam Jawa yang taat (santri) dan yang tidak taat (abangan) dalam menjalankan syariat Islam. $^{23}$ Simuh menjelaskan bahwa istilah santri merupakan warisan pra-Islam di

\footnotetext{
${ }^{21}$ Sofyan A. P. Kau, "Hermeneutika Gadamer dan Relevansinya dengan Tafsir," dalam Jurnal Farabi, Vol 11. No 1 (2014), 114.

${ }^{22}$ Adib Fathoni, "Santri dan Abangan dalam Kehidupan Keagamaan Orang Jawa," dalam Jurnal At-Taqaddum, Volume 4, Nomor 1 (2012), 104-105.

${ }^{23}$ Zamakhsari Dhofier, "Santri Abangan dalam Kehidupan Orang Jawa: Teropong dari Pesantren,” dalam Agama dan Tantangan Zaman (Jakarta: LP3ES, 1983) 180.
} 
Jawa. Santri berasal dari "mandala para sastrin" yang berarti tempat belajar para pelajar agama Hindu. Pada zaman Islam, tempat penginapan dan tempat belajar para murid tentang agama Islam juga terkenal dengan sebutan "pondok pesantren". Para pelajar disebut santri dan gurunya disebut kiai. Kemudian dalam perkembangannya, istilah santri mengarah pada orang-orang yang taat menjalankan perintah agama sesuai syariat yang ada. ${ }^{24}$

Namun menurut persepsi masing-masing, kaum santri beranggapan bahwa kaum abangan bukanlah orang kafir, melainkan orang Islam yang belum mendalami ajaran Islam dengan sungguhsungguh. Sedangkan kaum abangan beranggapan bahwa kaum santri merupakan tipe ideal bagi kehidupan beragama Islam yang sebenarnya. Masing-masing dari santri dan abangan saling berhubungan dan saling menarik persepsi positif satu sama lain. ${ }^{25}$

Jika ditinjau secara historis, yang melakukan kontak pertama dengan Islam di Jawa ialah adalah wilayah pesisir. Kawasan pesisir Barat Jawa Timur banyak dipengaruhi oleh kebudayaan Islam. Hal ini terbukti dengan adanya lima dari sembilan anggota Walisongo yang dimakamkan di kawasan pesisir tersebut. ${ }^{26}$ Kawasan ini meliputi wilayah Tuban, Lamongan dan Gresik. Meskipun kawasan ini dulu merupakan wilayah kerajaan Mataram yang berciri khas Islam kejawen, namun karena besarnya pengaruh Walisongo, kawasan ini mampu mempertahankan ciri khas budaya Jawa santri. Jika diamati lebih jauh, secara geografis wilayah pesisir relatif bercirikan santri dan wilayah pedalaman bercirikan abangan. Masyarakat santri identik dengan orang-orang Islam Jawa yang mengamalkan agama sesuai dengan syariat Islam. Sedangkan masyarakat abangan merupakan golongan orang-orang Jawa Islam yang mempraktikkan Islam secara sinkretis, bila dibandingkan dengan kelompok santri yang cenderung baku. ${ }^{27}$

Ideologi kaum santri dan masyarakat Islam pesisir tersebut telah mengkonstruksi pemikiran Misbah dalam menjalankan syariat, sebab

\footnotetext{
${ }^{24}$ Simuh, Munculnya Istilah Abangan, (Yogyakarta: Gelaria, 1987), 6.

${ }^{25}$ Dhofier, Santri Abangan, 182

${ }^{26}$ Nur Syam, Islam Pesisir (Yogayakarta: LkiS, 2005), 5-6.

${ }^{27}$ Konsepsi tersebut mengacu pada pemetaan Clifford Geertz terhadap kondisi sosio-religi masyarakat Jawa. Secara struktural, Geertz melihat bahwa dalam masyarakat Islam Jawa terdapat kultur yang variatif hingga dia membaginya kepada tiga tipologi, yaitu masyarakat santri, abangan dan priyayi. Cliffiord Geertz, Abangan, Santri, Priyayi dalam Masyarakat Jawa, terj. Aswab Mahasin (Jakarta: PT. Dunia Pustaka Jaya, 1981), 6-7.
} 
keduanya menjadi latar belakang sosio-historis yang melingkupinya. Misbah merupakan seorang tokoh agama Islam yang tumbuh dan berkembang daerah Jawa pesisir yang khas dengan kultur keberagamaan kaum santri. Ia juga tumbuh di lingkungan religius pondok pesantren. Semangat tersebut telah mengkonstruk pemikiran Misbah hingga ia menjadi sosok yang kritis terhadap praktik-praktik Islam sinkretik yang ada di masyarakat Jawa. Oleh sebab itulah Misbah cenderung keras dalam penafsirannya, terlebih jika menafsirkan ayat yang dianggap berkaitan dengan praktik keagamaan di masyarakat Jawa.

Masyarakat santri Jawa pesisir telah menjadi 'situasi hermeneutik' yang melingkupi Misbah. Situasi tersebut meliputi tradisi, kultur, ideologi dan pengalaman hidup yang mengitari kehidupan Misbah. Gadamer menyebut keniscayaan adanya affective history (sejarah yang memengaruhi seseorang), bahwa sejarah kehidupan, baik sadar ataupun tidak, sangat berperan besar dalam membentuk sebuah pemahaman. Pesan dari teori ini adalah bahwa seorang penafsir teks pasti tidak luput dari subjektivitas yang dipengaruhi oleh kesejarahan diri yang melingkupinya. ${ }^{28}$ Ideologi kaum santri di Jawa pesisir yang cenderung menjadikan syariat Islam sebagai acuan baku dalam beragama telah mengkonstruksi Misbah menjadi ulama yang kritis terhadap praktik-praktik keagamaan di masyarakatnya Jawa. Hingga dalam kitab tafsirnya, isu-isu demikian tidak luput dari pembahasan dan kritiknya.

\section{b. Bidah dan Syirik Perspektif Misbah Mustofa}

Sebelum mendefinisikan bidah, Misbah membagi bidah menjadi tiga jenis, yaitu: Pertama, bid'ah ittiqa'diyah yang merupakan bidah yang terkait erat dengan perkara itiqa $\bar{d} \bar{i}$ (keyakinan) atau suatu penemuan baru yang diikat dalam hati. Kedua, bid'ah 'ibädiyah, yaitu yang terkait dengan perkara ibadah atau suatu perbuatan yang pada dasarnya dimaksudkan agar mendapat pahala akhirat. Ketiga, bid'ah 'ádiyah, yaitu bidah yang terkait dengan perkara adat atau segala perbuatan yang dimaksudkan untuk memperoleh manfaat duniawi. ${ }^{29}$

\footnotetext{
${ }^{28}$ Hans George Gadamer, Truth and Method, terj. Joel Weinsheimer dan Donald G. Marshall (London: Continum, 2006), 300.

${ }^{29}$ Misbah Mustofa, Tafsìr Taj al-Muslimin Min Kalam Rabb al-'ÁAmin (Tuban: Majlis Ta'lif wa al-Khattat, 1989), 403-404.
} 
Dalam kitab tafsir Taj al-Muslimin, Misbah mendefinisikan bidah dengan membaginya menjadi definisi umum dan khusus. Bidah secara umum yaitu segala macam perbuatan yang tidak pernah ada di masa Nabi dan masa Sahabat. Ia mencontohkan seperti kegiatan naik sepeda dan makan menggunakan sendok. ${ }^{30}$ Mengutip Imām 'Izz alDin b. 'Abd al-Salām, bidah secara umum dibagi menjadi 5 macam: ${ }^{31}$ Mubāhah, Makrūh, Muḥarramah, Mandūbah, Wäjibah.

Kemudian tentang definisi bidah secara khusus, dalam kitab tafsirnya Misbah menyatakan:

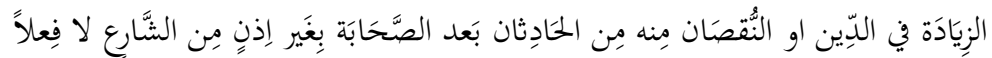

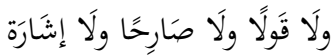

Mengadakan penambahan atau pengurangan terhadap perkara agama, yang muncul setelah masa sahabat tanpa ada izin shar $\bar{i}$ (Alquran dan Hadis Nabi), baik itu izin berupa perbuatan, ucapan, secara jelas ataupun secara isyarat tidak ditemukan.

Menurut Misbah, bidah secara khusus ini tidak dapat mencakup bid'ah 'ádiyah (adat), namun hanya mencakup sebagian bid'ah i'tiqädìyah dan sebagaian bid'ab 'ibädiyah. Contoh bidah i'tiqädiyah dalam hal ini adalah dalam tarekat, di mana guru tarekat umumnya menanamkan keyakinan terhadap para murid-muridnya. Misalnya dalam tarekat Naqsabandi, ketika seorang murid tarekat akan meninggal, salah satu tandanya adalah dia akan didatangi oleh para guru-guru terdahulu hingga didatangi oleh Shaykh Bahā al-Dīn al-Naqshābandi. Hal semacam ini artinya melakukan penambahan dalam keyakinan beragama. Bidah seperti inilah yang dicela oleh hadis: Ashäb al-bida" kiläb al-Nar. ${ }^{32}$ Contoh bidah dalam ibadah yaitu salat qabliyah secara berjamaah yang bisa ditemukan di sebagian kalangan kelompok tarekat. Hal ini tidak dilakukan oleh Nabi, maka itu merupakan penambahan dalam ibadah. ${ }^{33}$

Dalam perspektif hermeneutika Gadamer, pra-pemahaman Misbah atas bidah ini memengaruhi hasil penafsirannya terhadap QS. al-Baqarah [2]: 134. Pada penafsirannya tersebut, Misbah membolehkan praktik tahlilan yang masih pada tataran aktualisasi atas anjuran Nabi, yaitu zikir berjamaah. Oleh sebab itu, Misbah

\footnotetext{
${ }^{30}$ Ibid.

${ }^{31}$ Ibid.

${ }^{32}$ Ibid., 406.

${ }^{33}$ Ibid., 407.
} 
menggolongkan bidah ini kepada bidah mandübah atau bidah yang dianjurkan. Misbah mengkritik masyarakat yang beranggapan bahwa tahlilan harus dilakukan pada waktu-waktu tertentu dan dianggap tidak sah jika tidak melakukan sesuai tat aturan 'baku' tersebut, seperti harus ada mitung dino, nyatus dan baul. Menurutnya praktik tersebut merupakan bidah secara khusus yang mencakup dalam masalah keyakinan dan ibadah. Praktik demikian menurut Misbah merupakan bidah yang sesat.

Dalam menyikapi tahlilan yang menjadi tradisi keagamaan masyarakat Jawa, Misbah cenderung fleksibel ketika menghukumi tradisi tersebut. Misbah tampak berusaha menghadirkan kembali substansi ajaran Islam dalam ritus tahlilan dengan mengacu pada QS. al-Baqarah [2]: 134. Misbah menolak salah satu prosesi yang ada dalam tahlilan yaitu mengirimkan pahala bacaan Alquran kepada orang yang telah meninggal. Menurutnya, ayat tersebut memang ayat yang umum ('am), namun kemudian dikhususnya (takhsis) dengan hadis Nabi bahwa yang bisa sampai kepada mayit adalah pahala sedekah dan doa. Oleh sebab itu, dalam menafsirkan QS. al-Baqarah [2]: 134, dia berkesimpulan bahwa membacakan Alquran yang pahalanya ditujukan kepada mayit merupakan tindakan yang sia-sia dan tidak sejalan dengan Alquran dan hadis Nabi. Namun jika prosesi tahlilan itu diniatkan untuk zikir berjamaah dan dimaksudkan memohonkan ampun bagi mayit, maka termasuk kepada tradisi bidah yang justru dianjurkan. Terkait bidah dalam kasus ini, Misbah menjelaskan bahwa segala macam bidah menurut pandangan mazhab HAnafiyah adalah haram, sedangkan menurut mazhab Shāfīìah bidah itu makruh jika tidak bertentangan dengan nas Alquran ataupun sunah Rasul. Asumsi ini juga menjadi pra-pemahaman Misbah yang mengantarkannya pada hasil penafsiran demikian.

Selain bidah, pelabelan syirik juga identik dengan corak puritan yang digunakan untuk mengkritik segala praktik keagamaan yang dinilai tidak otentik dari Islam. Misi utama puritanisme adalah semangat mengembalikan Islam kepada ajaran yang murni dan menetralisir segala macam praktik keagamaan yang dianggap syirik. Praktik-praktik keagamaan yang mengarah kepada syirik ini menurut kaum puris banyak dilakukan oleh kaum sinkretis. Kaum sinkretis dianggap tidak sepenuhnya menjalankan syariat Islam sebab masih mencampuradukkan antara ajaran Islam dengan kepercayaan leluhur. Konsekuensi logis dari ideologi kaum puris ini adalah cenderung 
mudah memberi label syirik kepada praktik-praktik keagamaan yang telah menjadi tradisi dan telah lama mapan di masyarakat Jawa seperti slametan, ruwatan, tumpengan, dan nyadran.

Dalam hal ini, Misbah mendefiniskan syirik melalui penafsirannya terhadap QS. al-Baqarah [2]: 22. Melalui penafsirannya tersebut dia menyatakan bahwa syirik adalah perbuatan menyekutukan Allah dengan selain-Nya, baik persekutuan itu mengenai zat-Nya, af ${ }^{\prime} a l-\mathrm{Nya}$, ketaatan yang seharusnya ditujukan hanya kepada-Nya, maupun pemalingan hati kepada selain-Nya. ${ }^{34}$ Dia menuliskannya sebagai berikut:

"Syirik itu ada tiga macam dan ketiganya itu haram. Pertama, meyakini adanya sekutu-sekutu bagi Allah dalam hal ketuhananNya, disebut syirik besar. Syirik seperti ini adalah syirik yang dilakukan oleh kaum jahiliah. Syirik yang dimaksud firman Allah:

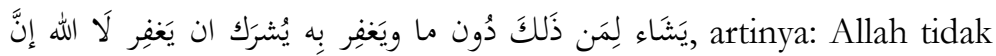
akan mengampuni perbuatan syirik dan mengampuni dosa selain syirik kepada hamba yang dikehendaki-Nya. Kedua, meyakini adanya sekutu Allah dalam hal perbuatan-Nya, yaitu keyakinan orang yang disebut kaum Qadariyah yang meyakini bahwa manusia dapat melakukan suatupekerjaan tanpa campur tangan Allah. Orang model ini juga disebut musyrik. Menurut ulama Ahlussunnah seluruh manusia tidak bisa berbuat apa-apa. Semua yang ada itu adalah ciptaan Allah baik yang terdapat di bumi ataupun di langit. Manusia, setan, malaikat, hewan dan segala hal yang bergerak dan diam lalu lintas takdir Allah. Namun, Allah yang Maha Agung membuat hukum 'ad $\bar{i}$ ' aq $\bar{l}$ dan shar $\bar{i}$ yang ketiganya itu berjalan. Oleh sebab itu, banyak orang yang bingung. Ketiga, menyekutukan sesuatu dengan Allah dalam ibadah, yaitu riya'. Riy $\bar{a}$ ' adalah melakukan perintah Allah sebab Allah dan sebab selain-Nya, seperti membaca Alquran di atas mimbar umum karena Allah dan karena tujuan untuk mendapat nomor satu, bisa mendapatkan banyak piala, seperti dalam MTQ. Syirik atau riya' seperti ini yang diterangkan dalam hadis-hadis." 35

Misbah membagi syirik kepada dua macam, yaitu syirik besar dan syirik kecil atau samar (syirik khafīi). Ciri-ciri syirik besar adalah menyekutukan Allah dengan selain-Nya, baik persekutuan itu mengenai zat-Nya, af al-Nya, ketaatan yang seharusnya ditujukan hanya kepada-Nya. Sedangkan syirik kecil adalah pemalingan hati

\footnotetext{
${ }^{34}$ Mustofa, Al-Iklïl, 702-703.

${ }^{35}$ Ibid., 702-703.
} 
kepada selain-Nya. Misbah menjelaskan secara detail mengenai syirik kecil ini dalam penafsirannya terhadap QS. al-Baqarah [2]: 112. Ia menyebutkan bahwa riya, merupakan perbuatan syirik kecil. Riya $\vec{a}$ merupakan penyakit hati yang bisa merusak amal dan ibadah serta dapat menjerumuskan kepada perbuatan syirik, sebab sikap tersebut sama halnya menyekutukan masyarakat dengan Allah agar masyarakat mengetahui ibadahnya. Syirik ini tidak termasuk sebagai tindakan yang dapat mengeluarkan seseorang dari agama. ${ }^{36}$ Riya ${ }^{\prime}$ yang mengarah kepada perbuatan syirik yang dimaksud Misbah adalah riya' dalam konteks ibadah.

Pemahaman Misbah terhadap syirik tersebut telah berperan dalam menentukan suatu perbuatan yang dianggap syirik atau tidak. Sebagaimana ia menyebutkan bahwa kegiatan perlombaan melantunkan Alquran dengan suara merdu atau biasa disebut MTQ (Musabaqah Tilawatil Qur'an) adalah perbuatan riya dalam ibadah atau termasuk kepada golongan syirik khafiz. Ia beranggapan bahwa para peserta MTQ cenderung bertujuan untuk memperoleh hadiah dari perlombaan tersebut. ${ }^{37}$ Oleh sebab itu, dia mengkritik keras kegiatan pertunjukan dan perlombaan MTQ karena berpotensi membawa seseorang kepada perbuatan riyà' bahkan menjerumuskan kepada perbuatan syirik.

Jika ditinjau dari perspektif hermeneutika Gadamer, syirik perspektif Misbah ini menjadi pra-pemahaman yang berpengaruh kepada penafsirannya terhadap QS. al-Baqarah [2]: 134. Anggapan Misbah tentang ketidakbolehan mengadakan tahlil pada waktu-waktu tertentu, sebagaimana yang telah disebutkan, telah dipengaruhi oleh pemahamannya terhadap syirik. Syirik yang terdapat pada praktik tersebut adalah meyakini bahwa keabsahan dan manfaat mendoakan orang yang telah meninggal tidak akan didapat jika tidak dilakukan pada hari-hari tertentu pasca meninggalnya seorang mayit. Maka, jika dilihat dengan perspektif syirik yang dikemukakan Misbah, praktik tersebut masuk dalam syirik secara batin atau abstrak. Sebagaimana yang dijelaskan oleh Misbah, yang ditekankan dalam perilaku syirik bukan hanya wujud konkret (nyata) penyembahan terhadap berhala, namun juga adanya keyakinan bahwa sesuatu tersebut dianggap memiliki sifat ketuhanan dan kekuatan tertentu yang dapat mendatangkan manfaat ataupan madarat.

${ }^{36}$ Mustofa, Taj al-Muslimin, 332.

${ }^{37}$ Mustofa, Al-Iklïl, 704. 
Gadamer menyatakan bahwa pemahaman seseorang tidak akan terlepas dari keterpengaruhan pengetahuan yang dimiliki sebelumnya (pra-pemahaman). Pengetahuan tersebut akan berperan penting dalam membentuk corak interpretasi seseorang. Oleh sebab itu, para pembaca (reader) perlu menyadari pra-pemahaman pengarang (author) dalam memahami teks yang dilahirkan guna memperoleh pemahaman yang komprehensif dan meletakkannya pada pemahaman yang proporsional. ${ }^{38}$ Sebagaimana penafsiran Misbah terhadap ayat-ayat tentang tema yang dibahas, corak pemikiran Islam puritan dalam penafsirannya telah dipengaruhi oleh pra-pemahaman tentang bidah dan syirik. Perspektif Misbah terhadap bidah dan syirik telah memengaruhi hasil interpretasi yang cenderung kepada corak puritanisme, walaupun tidak sepenuhnya, dan hanya pada tatarantataran tertentu. Pelabelan bidah dan syirik terhadap praktik yang ada dalam tahlilan merupakan konsekuensi logis yang lahir dan dipengaruhi oleh paradigma intelektual yang melingkupinya. Oleh sebab itu, Misbah cenderung bersikap keras dan tanpa kompromi dalam menyikapi persoalan-persoalan keagamaan yang menurutnya melenceng dari ajaran Islam.

\section{Antara Misbah Mustofa dan Kelompok Islam Puritan}

Membandingkan pemikiran Misbah dengan kelompok Islam Puritan merupakan hal yang cukup penting untuk mengetahui dan meletakkan secara proporsional posisi pemikiran Misbah terhadap isu puritanisme yang ada dalam Islam. Dalam hal ini, kelompok Islam puritan diwakili oleh gerakan Salafi-Wahabi yang mengusung ideologi puritan dan egaliterian. Egaliterian yang dimaksud di sini adalah anggapan bahwa semua umat Islam berhak merujuk secara langsung sumber utama pedoman umat Islam, yaitu Alquran dan Sunnah tanpa harus melalui penafsiran-penafsiran para ulama.

Gerakan Salafi-Wahabi pada mulanya merupakan gerakan yang diilhami oleh gagasan Ibn Taymiyah pada abad ke-14 . Ibn Taymiyah menggagas bahwa dalam rangka mengentaskan kejumudan berpikir dan beragama, maka pintu ijtihad dibuka kembali. Hal ini guna menacapai Islam yang kafah sebagaimana Islam pada masa Nabi dan Salaf al-Săliḥ (Sahabat dan Tabiin). ${ }^{39}$ Oleh sebab itu, dia

\footnotetext{
${ }^{38}$ Hans George Gadamer, "Text and Interpretation," dalam B.R. Wacherhauser (ed.), Hermeneutics and Modern Philosophy (New York: SUNY Press, 1986), 379.

${ }^{39}$ Sutiyono, Benturan Budaya, 147.
} 
menggaungkan gerakan kembali pada Alquran dan Sunah. Karena gagasan tersebut, Ibn Taymiyah dianggap sebagai tokoh kebangkitan Islam (Islam revivalis).

Gerakan Salafi-Wahabi kemudian menjadi kanal baru bagi gagasan Ibn Taymiyah yang lahir sebagai gerakan pembaharu Islam. Gagasan puritanisme Islam yang belum sempat terealisasi pada masa Ibn Taymiyah dapat diwujudkan secara nyata pada masa gerakan Muhammad b. 'Abd al-Wahhāb pada abad ke-18. Gagasan kembali kepada Alquran dan Sunah yang disuarakan oleh gerakan SalafiWahabi merupakan upaya untuk mengangkat kembali pola kehidupan masyarakat Islam di zaman Nabi Muhammad. Muhammad b. 'Abd alWahhāb menyatakan bahwa kembali kepada Alquran dan Sunah merupakan gagasan untuk kembali menghayati dan mengamalkan secara nyata dan sungguh-sungguh terhadap semua perintah-perintah Allah. ${ }^{40}$ Pada akhirnya, gerakan Salafi-Wahabi justru mengarah kepada pola pikir konservatif yang ingin mengembalikan Islam pada romantisme masa lalu, tepatnya seperti pada masa Nabi dan Sahabat.

Setelah pertemuan antara Muhammad b. 'Abd al-Wahhāb dengan tokoh politik Arab pada waktu itu, Sa ưd, gerakan ini menjelma sebagai gerakan yang mengarah pada tindakan radikal dalam menegakkan syariat Islam. Gerakan Salafi-Wahabi mendapatkan dukungan politik dari Sa úud, sebab mereka memiliki visi yang sama untuk mengembalikan masyarakat Arab Islam pada ajaran dan kehidupan era Nabi. Gerakan ini tidak sungkan untuk menghancurkan situs-situs peninggalan masa lalu yang dianggap sakral oleh masyarakat Arab pada waktu itu.

Gerakan Salafi-Wahabi memiliki dasar klaim bahwa agama Islam yang dipahami masyarakat telah mengalami distorsi dari ajaran Nabi, sehingga mereka merasa berkepentingan untuk menyerukan kembali kepada ortodoksi syariah dengan memurnikan Islam sesuai kriteria Alquran dan Sunah. Karakteristik yang menjadi platform gerakan ini antara lain: Pertama, memiliki kecenderungan interpretasi literal terhadap teks-teks agama. Pemahaman kontekstual dianggap dapat mereduksi kesucian agama itu sendiri. Kedua, menolak pluralisme dan relativisme, sebab menurutnya dua hal ini merupakan tindakan yang mengakibatkan distorsi pemahaman terhadap ajaran agama. Ketiga, cenderung memonopoli kebenaran atas tafsir agama. Gerakan ini

${ }^{40}$ Ibid., 148. 
melahirkan anggapan bahwa mereka adalah pemegang otoritas penafsir agama yang paling absah, sehingga cenderung menganggap sesat kelompok lain di luar mereka. ${ }^{41}$

Secara esensial, visi dakwah Misbah Mustofa senada dengan gerakan Salafi-Wahabi. Dalam mukadimah kitab tafsirnya, motivasi Misbah menulis kitab tafsir adalah ingin menciptakan masyarakat yang qur'ani, yaitu masyarakat yang mampu menghayati dan mengamalkan secara nyata dan sungguh-sungguh terhadap pesan-pesan Allah yang termaktub dalam Alquran. Lalu, kitab tafsir yang ia tulis bertujuan agar masyarakat Islam dapat berdialog langsung dengan pesan-pesan Alquran dan supaya tidak terlalu menggantungkan diri terhadap para ulama ataupun kiai dalam beragama. ${ }^{42}$ Secara implisit, gagasan Misbah tampak memiliki kesamaan orientasi dengan Ibn Taymiyah yang ingin membebaskan masyarakat Islam dari pemikiran jumud yang merupakan imbas dari sistem bermazhab.

Mengenai sistem bermazhab, Misbah tampak berbeda dengan kelompok Salafi-Wahabi. Ketika Salafi-Wahabi bergerak dalam rangka meruntuhkan sistem mazhab dalam agama yang dianggap pelik dan runyam, sebaliknya Misbah mempraktikkan sistem mazhab tersebut. Dalam kitab tafsirnya, banyak pendapat yang dinukil dari imam-imam mazhab. Misbah tidak menolak sistem bermazhab dalam beragama, yang dia kritik adalah kecenderungan umat Islam masa sekarang yang melakukan taklid buta. Oleh sebab itulah, dia menulis kitab tafsir dalam rangka memberikan wawasan bagi umat Islam agar mengetahui setiap hujah atas setiap aktivitas ibadahnya, serta agar masyarakat Islam bersikap kritis dalam beragama. ${ }^{43}$

Perlu diakui bahwa antara Misbah dengan kelompok SalafiWahabi memiliki kesamaan fondasi dalam kerangka pemikiran, yaitu menjadikan Alquran sebagai acuan utama dalam seluruh aspek kehidupan. Konsekuensi atas gagasan ini adalah corak pemikiran yang cenderung konservatif dan skripturalis. Namun, kadar konservatisme Misbah dengan kelompok Salafi-Wahabi tampak berbeda ketika melakukan aktualisasi gagasan tersebut. Ketika dihadapkan dengan tradisi sinkretik berupa tahlilan, Misbah lebih memilih mengkritisi

\footnotetext{
${ }^{41}$ Umma Farida, "Islam Pribumi dan Islam Puritan: Ikhtiar Menemukan Wajah Islam Indonesia Berdasar Proses Dialektika Pemeluknya dengan Tradisi Loka," dalam Fikrab: Jurnal Ilmu Aqidah dan Studi Keagamaan, vol. 3, no. 1 (2015), 148.

${ }^{42}$ Mustofa, Taj al-Muslimin, 4.

${ }^{43}$ Ibid.
} 
kembali praktik tersebut, dengan menawarkan ijtihad alternatifnya, daripada melarangnya secara total sebagaimana yang dilakukan oleh kelompok Salafi-Wahabi. Hasilnya, konservatisme Misbah yang diaktulisasikan dengan mengedepankan nalar kritis terlebih dahulu tidak menolak praktik sinkretik tersebut, melainkan lebih kepada upaya rekonstruksi tradisi tahlilan. Misbah tidak melarang tradisi tahlilan yang merupakan gubahan atas tradisi slametan dan ruwatan dari ajaran agama sebelumnya. Mengacu pada QS. al-Baqarah [2]: 134, dia menolak pembacaan QS. Yasin maupun surah-surah lain yang pahalanya diniatkan dan dikhususkan bagi mayit, di mana prosesi tersebut ada dalam praktik tahlilan.

Pada kesimpulannya, corak pemikiran Misbah memiliki kesamaan dengan kelompok Salafi-Wahabi. Kesamaan tersebut tampak pada semangat menjadikan masyarakat yang berperilaku qur'ani dalam semua aspek kehidupan. Semangat ini menolak relativisme yang dianggap dapat menyebabkan distorsi pesan-pesan Alquran. Prinsip ini kemudian menjelma menjadi corak berpikir yang skripturalis dan literalis. Corak pemikiran tersebut melahirkan sikap konservatif terhadap hal-hal baru di luar Islam.

Perbedaan Misbah dengan kelompok Salafi-Wahabi adalah ketika dihadapkan dengan tradisi sinkretik. Ketika Salafi-Wahabi memilih untuk menolak secara total praktik-praktik keagamaan yang berifat sinkretik, Misbah lebih mengedepankan sikap kritisnya dan lebih memilih untuk merekonstruksi tradisi tersebut. Sebagaimana dia membolehkan tradisi tahlilan namun dengan syarat-syarat tertentu yang sesuai dengan Alquran dan hadis. Kemudian, jika kelompok Salafi-Wahabi mengusung sikap egaliter dalam rangka mendobrak sistem bermazhab dalam agama, sebaliknya, Misbah sepakat dengan hal itu. Yang dikritik oleh Misbah adalah sikap taklid buta masyarakat Islam yang terlalu mengkultuskan pola pikir mazhabi.

\section{Keseimbangan Sikap Konservatif dan Permisif dalam Beragama}

Dalam ranah teoritis, terdapat dua konsep penting yang dimiliki oleh setiap agama, yang dapat memengaruhi pemeluknya dalam interaksi di antara mereka, yaitu fanatisme dan toleransi. Dua konsep ini selalu dipraktikkan dalam pola yang seimbang, sebab jika terjadi ketidakseimbangan di antara keduanya, maka akan terjadi 
ketidakstabilan antar pemeluknya. ${ }^{44}$ Jika fanatisme terlalu kuat sedangkan toleransi rendah, maka eksistensi agama akan menguat dan cenderung menimbulkan permusuhan dengan agama atau kelompok lain. Sebaliknya, jika fanatisme terlalu lemah sementara toleransi tinggi, maka eksistensi agama atau kelompoknya menjadi melemah sebab merasa tidak bangga dengan apa yang diyakininya. ${ }^{45}$

Hal dilematis itu yang dirasakan Misbah dalam kehidupan sosioreligi di masyarakatnya. Secara implisit, Misbah tampak berusaha menepis sikap toleransi yang terlalu tinggi dalam beragama yang tanpa diimbangi kedalaman ilmu dan akidah. Seperti ketika dia mengkritik ulama yang cenderung membiarkan dan membolehkan berdoa menggunakan pengeras suara. Hal demikian bagi Misbah merupakan suatu tindakan yang terlalu permisif ketika menghadapi perkembangan zaman, hingga menyebabkan pengabaian terhadap pesan-pesan Alquran. Menurutnya, akar dari semua itu adalah sikap para ulama yang terlalu lunak kepada umatnya. ${ }^{46}$ Sikap demikianlah yang dianggap Misbah sebagai penyebab terkikisnya eksistensi ajaran Islam.

Ketika tradisi dan agama tidak sejalan, Misbah lebih mengedepankan agama dari pada mengkompromikan keduanya. Namun jika dilihat secara proporsional, justru ia mengusung gagasan berislam secara kritis. Corak pemikiran puritanisme pada Misbah masih dalam tataran-tataran tertentu. Hal ini terlihat ketika ada beberapa toleransi atau pengecualian atas praktik-praktik yang dia kritik. Secara implisit, Misbah tampak ingin menunjukkan bahwa beragama haruslah diimbangi dengan sikap kritis, khususnya ketika melakukan praktik-praktik sinkretik yang ada di masyarakat. Bahkan dia tidak menolak tradisi keagamaan yang ada di masyarakatnya, Misbah tampak menekankan pentingnya menjaga kemurnian iman demi menjaga keberlangsungan tradisi di masyarakat. Maka dengan itu, eksistensi antara ajaran Islam dengan tradisi yang telah ada di masyarakat akan tetap berlangsung.

\section{Kesimpulan}

Dari paparan di atas, penulis berargumen bahwa aspek kritisisme Misbah Mustofa dalam pemikiran tafsirnya bukan ditujukan terhadap

\footnotetext{
${ }^{44}$ Endang Turmuzi dan Riza Sihbudi, Islam dan Radikalisme di Indonesia, (Jakarta: LIPI Press, 2005).

${ }^{45}$ Sutiyono, Benturan Budaya, i.

${ }^{46}$ Mustofa. Taj al-Muslimin, 586.
} 
ajaran yang telah mapan, namun lebih pada upaya kritisisme purifikatif terhadap ajaran-ajaran Islam. Penafsiran Misbah yang bercorak puritan, sebagaimana dipaparkan dengan perspektif hermeneutika Gadamer, disebabkan oleh beberapa faktor, di antaranya: Pertama, ideologi kaum santri Jawa Pesisir yang menjadikan syariat Islam sebagai acuan paten dan baku dalam beragama. Ideologi ini cenderung kritis terhadap tradisi sinkretis dalam masyarakat Jawa. Kedua, prapemahaman Misbah tentang bidah dan syirik. Jika bidah tersebut dalam ranah 'ubuidiyah dan itiqädiyah, maka dianggap sesat dan dilarang. Ketiga, penafsiran yang berbasis pada arti umum ('am) ayat. Metodologi dengan pendekatan tektstualis yang cenderung mengedepankan aspek internal teks serta kurang melihat aspek kemaslahatan dalam kehidupan sosio-religi masyarakat. Meaningful sense atau nilai yang tercermin atas sikap Misbah dalam kajian ini yaitu kritis dalam beragama serta meletakkan sikap permisif dan konservatif secara proporsional, agar eksistensi antara agama dan tradisi terjaga.

\section{Daftar Pustaka}

Ahimsa, Heddy Shri. "The Living Alquran: Beberapa Perspektif Antropologi." Jurnal Walisongo, Vol. 20 No. 1 (2012).

Baidowi, Ahmad. "Aspek Lokalitas Tafsir Al-Iklil Fi Ma'ani Al-Tanzil Karya KH Misbah Mustofa”. Jurnal NUN, Vol. 1, No. 1 (2015).

Dhofier, Zamakhsari. "Santri Abangan dalam Kehidupan Orang Jawa:

Teropong dari Pesantren." Agama dan Tantangan Zaman. Jakarta: LP3ES, 1983.

Farida, Umma. "Islam Pribumi dan Islam Puritan: Ikhtiar Menemukan Wajah Islam Indonesia Berdasar Proses Dialektika Pemeluknya dengan Tradisi Loka." Fikrah: Jurnal Ilmu Aqidah dan Studi Keagamaan, vol. 3, no. 1 (2015).

Fathoni, Adib. "Santri dan Abangan dalam Kehidupan Keagamaan Orang Jawa." Jurnal At-Taqaddum, Volume 4, Nomor 1 (2012).

Fattah, Munawar Abdul. Tradisi Orang-orang NU. Yogyakarta: Pustaka Pesantren, 2006.

Gadamer, Hans Georg. "Text and Interpretation." B.R. Wacherhauser (ed.). Hermenentics and Modern Philosophy. New York: SUNY Press, 1986. Truth and Method. terj. Joel Weinsheimer dan Donald G. Marshall. London: Continum, 2006. 
Geertz, Cliffiord. Abangan, Santri, Priyayi dalam Masyarakat Jawa. terj. Aswab Mahasin. Jakarta: PT. Dunia Pustaka Jaya, 1981.

Gusmian, Islah. "Tafsir Alquran Bahasa Jawa: Peneguhan Identitas, Ideologi, dan Politik.” Jurnal Subuf, Vol. 9, No. 1 (2016). "Tafsir Alquran di Indonesia: Sejarah dan Dinamika." NUN Jurnal Studi Alqur'an dan Tafsir di Nusantara, Vol. 1, No. 1, (2015).

Hardiman, F. Budi. Seni Memahami: Hermeneutika Dari Scheleiermacher Sampai Derida. Yogyakarta: Kanisius. 2016.

Kau, Sofyan A. P.. "Hermeneutika Gadamer dan Relevansinya dengan Tafsir." Jurnal Farabi, Vol 11. No 1 (2014).

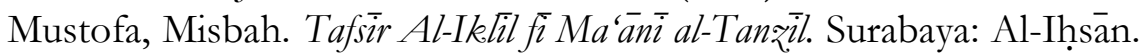
t.th.

Mustofa, Misbah. Tafsì Taj al-Muslimin Min Kalam Rabb al-'Alamīn. Tuban: Majlis Ta’'if wa al-Khațtat, 1989.

Supriyanto. "Alquran dalam Ruang Keagamaan Islam Jawa”. Jurnal THEOLOGLA, Vol. 28, Nomor 1 (2017).

Sutiyono. Benturan Budaya Islam Puritan dan Sinkretis. Jakarta: Kompas, 2010.

Syam, Nur. Islam Pesisir. Yogayakarta: LkiS, 2005.

Taufikurrahman. "Kajian Tafsir di Indonesia". Jurnal Mutawatir: Jurnal Keilmuan Tafsir Hadis, Vol. 2, No. 1 (2012).

Turmuzi, Endang dan Riza Sihbudi. Islam dan Radikalisme di Indonesia. Jakarta: LIPI Press, 2005. 